\title{
Contributions of Cathepsin A and Carboxylesterase 1 to the hydrolysis of Tenofovir Alafenamide in the Human Liver, and the Effect of CES1 Genetic Variation on Tenofovir Alafenamide Hydrolysis
}

Jiapeng $\mathrm{Li}^{1}$, Jian Shi ${ }^{1}$, Jingcheng Xiao, Lana Tran, Xinwen Wang, Hao-Jie Zhu*

Department of Clinical Pharmacy, University of Michigan, Ann Arbor, MI, 48109-1065 (J.L., H-J, Z.)

Alliance Pharma, Inc, Malvern, PA, 19355 (J.S.)

Department of Pharmaceutical Sciences, University of Michigan, Ann Arbor, MI, 48109-1065 (J.X.)

Clinical Pharmacology and Pharmacometrics, Janssen Research \& Development, LLC, Spring House, Pennsylvania, 19477 (L.T.)

Department of Pharmaceutical Sciences, Northeast Ohio Medical University, Rootstown, OH, 44272 (X.W.)

${ }^{1}$ The authors contributed equally to the project. 
Running title: TAF-hydrolyzing enzymes in the liver and pharmacogenetics

* Corresponding author:

Hao-Jie Zhu, Department of Clinical Pharmacy, University of Michigan

428 Church St. Ann Arbor, MI, 48109-1065, USA

ORCID: orcid.org/0000-0002-2248-4419

E-mail: hjzhu@med.umich.edu

Number of text pages: 27

Number of tables: 1

Number of figures: 4

Number of references: 49

Number of words in Abstract: 243

Number of words in Introduction: 721

Number of words in Results and Discussion: 2381 


\section{Abbreviations:}

AASLD: American Association for the Study of Liver Diseases

ACN: acetonitrile

BNPP: bis-(p-nitrophenyl) phosphate

CatA: cathepsin A

CES1: carboxylesterase 1

DIA: data-independent acquisition

FDA: Food and Drug Administration

HBV: hepatitis B virus

HINT1: histidine triad nucleotide-binding protein 1

HIV: human immunodeficiency virus

HLS9: human liver S9 fractions

LC-MS/MS: liquid chromatography-tandem mass spectrometry

MS: mass spectrometry

RDV: remdesivir

TAF: tenofovir alafenamide

TDF: tenofovir disoproxil

TFV: tenofovir

TFV-Ala: tenofovir-alanine

TFV-DP: tenofovir diphosphate

\section{Keywords:}

Carboxylesterase 1 (CES1); Cathepsin A (CatA); Hydrolases; Pharmacogenetics; Tenofovir alafenamide. 


\section{Abstract}

The prodrug tenofovir alafenamide (TAF) is a first-line antiviral agent for the treatment of chronic hepatitis B infection. TAF activation involves multiple steps, and the first step is an ester hydrolysis reaction catalyzed by hydrolases. This study was to determine the contributions of carboxylesterase 1 (CES1) and cathepsin $\mathrm{A}$ (CatA) to TAF hydrolysis in the human liver. Our in vitro incubation studies showed that both CatA and CES1 catalyzed TAF hydrolysis in a $\mathrm{pH}$-dependent manner. At their physiological pH environment, the activity of CatA (pH 5.2) was approximately 1,000-fold higher than that of CES1 (pH 7.2). Given that the hepatic protein expression of CatA was approximately 200-fold lower than that of CES1, the contribution of CatA to TAF hydrolysis in the human liver was estimated to be much greater than that of CES1, which is contrary to the previous perception that CES1 is the primary hepatic enzyme hydrolyzing TAF. The findings were further supported by a TAF incubation study with the CatA inhibitor telaprevir and the CES1 inhibitor bis-(p-nitrophenyl) phosphate. Moreover, an in vitro study revealed that the CES1 variant G143E (rs71647871) is a loss-of-function variant for CES1-mediated TAF hydrolysis. In summary, our results suggest that CatA may play a more important role in the hepatic activation of TAF than CES1. Additionally, TAF activation in the liver could be affected by CES1 genetic variation, but the magnitude of impact appears to be limited due to the major contribution of CatA to hepatic TAF activation. 


\section{Significance statement}

Contrary to the general perception that carboxylesterase 1 (CES1) is the major enzyme responsible for tenofovir alafenamide (TAF) hydrolysis in the human liver, the present study demonstrated that cathepsin $A(C a t A)$ may play a more significant role in TAF hepatic hydrolysis. Furthermore, the CES1 variant G143E (rs71647871) was found to be a loss-of-function variant for CES1-mediated TAF hydrolysis. 


\section{Introduction}

Tenofovir (TFV) is an acyclic nucleotide phosphonate analog that potently inhibits the hepatitis $B$ virus (HBV) DNA polymerase, a key enzyme required for viral genome replication (Trepo et al., 2014). However, the poor bioavailability of TFV is a significant limitation (Kearney et al., 2004). Tenofovir disoproxil (TDF), a bis-carbonate ester prodrug of TFV, was subsequently developed due to its enhanced stability and improved oral bioavailability (Rautio et al., 2008). Although TDF can achieve sustained viral suppression with a high barrier to drug resistance, its long-term use has been associated with renal toxicity and reduced bone mineral density because of its high plasma TFV level (Cooper et al., 2010; Buti et al., 2015; Bedimo et al., 2016). Consequently, a new TFV prodrug, tenofovir alafenamide (TAF), was developed for more efficient delivery into target tissues and cells. TAF exhibits a higher antiviral potency at $~ 10 \%$ of the TDF dose and an improved safety profile due to the reduced systemic exposure of TFV (Babusis et al., 2013; Agarwal et al., 2015; Murakami et al., 2015). TAF was listed as one of the four first-line antiviral agents in the latest American Association for the Study of Liver Diseases (AASLD) guidance for chronic hepatitis B treatment (2018) (Terrault et al., 2018). Despite these improvements, significant interindividual variability in both the pharmacokinetics (PK) and antiviral activity of TAF has been consistently observed in clinical studies (Markowitz et al., 2014; Agarwal et al., 2015; Custodio et al., 2016).

As a prodrug, the antiviral effect of TAF relies on multistep activation involving several enzymes (Figure 1) (Birkus et al., 2008b; Murakami et al., 2015).

Therefore, identifying the key TAF activating enzymes is critical to understand the interindividual variability in the PK and pharmacodynamics (PD) of TAF therapy. Multiple hydrolases, including cathepsin A (CatA), carboxylesterase 1 (CES1), leukocyte elastase, pancreatic elastase 1 , proteinase 3 , and cathepsin $\mathrm{H}$, have been shown to catalyze the cleavage of the ester group, forming the intermediate metabolite tenofovir-alanine (TFV-Ala), the first step in the TAF activation process (Birkus et al., 2008b; Birkus et al., 2016). Unsurprisingly, this step depends on the composition of hydrolases in different cells and tissues. For example, CatA was 
reported as the primary enzyme hydrolyzing TAF in peripheral blood mononuclear cells, the target cells of the human immunodeficiency virus (HIV) (Birkus et al., 2007; Birkus et al., 2016); and CES1 was considered to be the major hydrolase catalyzing the first activation step of TAF in the human liver, the target tissue of HBV (Henningsson et al., 2005; Murakami et al., 2015). However, the contributions of individual hydrolases in TAF hydrolysis in the liver have not been fully evaluated because the expression profiles of hepatic hydrolases were not taken into consideration in the previous study (Murakami et al., 2015). In addition, the CES1 activity in the previous study was measured with porcine liver carboxylesterase (Birkus et al., 2008b), which may differ from human CES1 in terms of catalyzing TAF hydrolysis.

CES1 is one of the most abundant proteins in the human liver and has been considered the major contributor to the hepatic hydrolysis of many ester-containing drugs, including TAF (Imai, 2006; Murakami et al., 2015; Wang et al., 2020). CES1 function can be regulated by genetic variants, such as the loss-of-function nonsynonymous variant G143E (rs71647871) (Zhu et al., 2008; Her and Zhu, 2020). However, it remains unknown whether and to what extent the G143E variant may affect TAF activation.

Therefore, the purposes of this study were to 1) evaluate the contributions of CES1 and CatA to TAF hydrolysis in the human liver; and 2) determine the impact of the CES1 genetic polymorphism G143E on TAF hydrolysis. We performed an absolute quantitative proteomics analysis to determine the protein levels of CES1, CatA, and other hydrolases in human liver S9 fractions (HLS9). We also conducted an in vitro TAF hydrolysis study and found that the activities of CatA, CES1, and HLS9 on hydrolyzing TAF were pH-dependent. Moreover, we determined the kinetic parameters of CatA and CES1-catalyzed TAF hydrolysis. Based on the obtained proteomics and enzymatic activity data, it appears that, while both CatA and CES1 are capable of hydrolyzing TAF, the contribution of CatA in human hepatic hydrolysis of TAF could be substantially greater than that of CES1. Additionally, the G143E was found to be a loss-of-function variant for the CES1-mediated TAF hydrolysis. 


\section{Method}

\section{Materials}

TAF, remdesivir (RDV), bortezomib, and boceprevir were purchased from Cayman Chemical (Ann Arbor, MI). TFV and adefovir (AFV) were obtained from MP Biomedicals (Santa Ana, CA, USA). Recombinant human CatA (rhCatA), CES1 (rhCES1) were purchased from R\&D Systems (Minneapolis, MN, USA); Bis-(p-nitrophenyl) phosphate (BNPP) and Tris-base (Trizma base) were purchased from Sigma-Aldrich (St. Louis, MO). Tris-HCl was purchased from Fisher Scientific (Fair lawn, NJ, USA). Pierce BCA protein assay kit and phosphate-buffered saline were obtained from Thermo Fisher Scientific (Waltham, MA, USA). The MES [2-(N-morpholino) ethanesulfonic acid] buffer (0.2 M, pH 5.5 at $25^{\circ} \mathrm{C}$ and $\mathrm{pH} 5.2$ at $37^{\circ} \mathrm{C}$ ) was purchased from Alfa Aesar (Ward Hill, MA, USA). All other chemicals and reagents were of analytical grade and commercially available. Pooled HLS9 was purchased from XenoTech LLC (Kansas City, KS).

\section{Cell S9 fractions preparation}

The Flp-In 293 cell lines stably expressing wild-type CES1 and the variant G143E were developed in our previous study, and CES1 protein expression levels are comparable between the two cell lines (Zhu et al., 2008). Cells were sonicated and centrifuged at $9,000 \mathrm{~g}$ for $30 \mathrm{~min}$ at $4{ }^{\circ} \mathrm{C}$. The supernatant (S9 fractions) was collected and stored at $-80^{\circ} \mathrm{C}$ until use. The $\mathrm{S} 9$ fraction protein concentrations were measured using a Pierce BCA protein assay kit.

\section{rhCES1 and rhCatA activity assays}

The activity of rhCES1 and rhCatA on hydrolyzing TAF was measured using the method similar to that from a previous report (Murakami et al., 2010). A preliminary experiment was performed to determine the steady-state kinetic conditions for the enzymatic reactions (Supplemental Figure S1). The assay buffer for the rhCES1 and rhCatA activity assays was different in composition and $\mathrm{pH}$. The assay buffer for rhCatA reactions was an MES buffer $(0.2 \mathrm{M}, \mathrm{pH} 5.2$ at $37^{\circ} \mathrm{C}$ ), containing $100 \mathrm{mM} \mathrm{NaCl}, 1 \mathrm{mM} \mathrm{DTT}$, and $0.1 \%$ Nonidet (Murakami et al., 
2010). The buffer for rhCES1 reactions was $50 \mathrm{mM}$ Tris buffer, which was prepared by dissolving $6.06 \mathrm{~g}$ Tris-HCL and $1.39 \mathrm{~g}$ Tris-base in $1000 \mathrm{~mL}$ water $\left(\mathrm{pH} 7.2\right.$ at $37^{\circ} \mathrm{C}$ ). TAF was stable in both buffers for at least $30 \mathrm{~min}$ at $37^{\circ} \mathrm{C}$ (Supplemental Figure S2).

The CatA assay was conducted in $50 \mu \mathrm{L}$ MES pH 5.2 assay buffer, containing the activated rhCatA $(0.2 \mathrm{ng} / \mu \mathrm{L})$ and various concentrations of $\operatorname{TAF}(10,20,50$, and $100 \mu \mathrm{M})$. The rhCatA assay mixtures were incubated at $37^{\circ} \mathrm{C}$ for $5 \mathrm{~min}$. The reaction was terminated by adding a two-fold volume of acetonitrile (ACN) containing the internal standard RDV $(5 \mu \mathrm{M})$. The samples were then vortexed for 15 seconds and centrifuged at $15,000 \mathrm{rpm}$ at $4^{\circ} \mathrm{C}$ for $10 \mathrm{~min}$. The supernatant was collected and centrifuged again using the same condition to remove the precipitated proteins. The resulting supernatant was collected and diluted with a four-fold volume of $66.7 \%$ methanol (methanol: water, $2: 1, \mathrm{v} / \mathrm{v}$ ) for liquid chromatography-tandem mass spectrometry (LC-MS/MS) analysis.

The rhCES1 activity study was conducted in $10 \mu \mathrm{L}$ Tris buffer ( $\mathrm{pH} 7.2$ ), containing $40 \mathrm{ng} / \mu \mathrm{L}$ rhCES1 and various concentrations $(10,20,50$, and $100 \mu \mathrm{M})$ of TAF. The rhCES1 reaction mixtures were incubated at $37^{\circ} \mathrm{C}$ for $20 \mathrm{~min}$. The reaction was terminated by adding a five-fold volume of ACN containing the internal standard RDV $(2 \mu \mathrm{M})$. The samples were then vortexed for 15 seconds and centrifuged at $15,000 \mathrm{rpm}$ at $4^{\circ} \mathrm{C}$ for $10 \mathrm{~min}$ to remove the precipitated proteins. The centrifugation was repeated once, and the resulting supernatant was collected for LC-MS/MS analysis.

The TAF hydrolysis activity was calculated by dividing the reduction of TAF concentration after incubation by the protein concentrations of the recombinant enzymes or HLS9 and incubation time.

\section{pH-dependent TAF hydrolysis}

To evaluate the effect of $\mathrm{pH}$ on enzymatic activity, rhCES1 $(40 \mathrm{ng} / \mu \mathrm{L})$ and rhCatA $(0.25 \mathrm{ng} / \mu \mathrm{L})$ were incubated with $20 \mu \mathrm{M} \mathrm{TAF}$ at $37^{\circ} \mathrm{C}$ in the MES assay buffer (pH 5.2) for $20 \mathrm{~min}$ and the Tris buffer ( $\mathrm{pH} \mathrm{7.2)}$ for $10 \mathrm{~min}$, respectively. Our preliminary study confirmed that TAF hydrolysis was in a linear relationship with the enzyme concentrations (CatA: 0.1 - $0.5 \mathrm{ng} / \mu \mathrm{L} ; \mathrm{CES} 1: 20$ - $40 \mathrm{ng} / \mu \mathrm{L}$ ) and the 
incubation duration (CatA: 0 - $5 \mathrm{~min}$; CES1: 0 - $30 \mathrm{~min})$. Moreover, TAF (20 $\mu \mathrm{M})$ was incubated with HLS9 $\left(0.5 \mathrm{mg} / \mathrm{mL}\right.$ HLS9 protein) at $37^{\circ} \mathrm{C}$ for $15 \mathrm{~min}$ in both MES pH 5.2 assay buffer and Tris pH 7.2 buffer. All reactions were performed on a shaker (Benchmark, Multi-Therm ${ }^{\mathrm{TM}}$ ) at 1,500 rpm and terminated by adding a two-fold volume of ACN containing the internal standard RDV $(5 \mu \mathrm{M})$. Samples were vortexed for 15 seconds and centrifuged twice at $15,000 \mathrm{rpm}$ at $4^{\circ} \mathrm{C}$ to remove the precipitated proteins. The resulting supernatant was collected and diluted with a four-fold volume of $66.7 \%$ methanol. The remaining TAF after incubation was determined using an LC-MS/MS assay.

\section{CatA and CES1 Inhibition study}

An in vitro study was conducted to evaluate the effects of telaprevir (CatA inhibitor) and BNPP (CES1 inhibitor) on TAF hydrolysis. The remaining TAF concentration was determined after incubation of TAF $(20 \mu \mathrm{M})$ with pooled HLS9 at $37^{\circ} \mathrm{C}$ for 10 $\mathrm{min}$ in the absence or presence of various concentrations of telaprevir $(0.5,5$, and $50 \mu \mathrm{M})$ and BNPP $(1,10$, and $50 \mu \mathrm{M})$ in the MES pH 5.2 assay buffer and Tris $\mathrm{pH}$ 7.2 buffer. TAF was incubated with $0.5 \mathrm{mg} / \mathrm{mL}$ HLS9 for $15 \mathrm{~min}$ in the MES pH 5.2 buffer, whereas the TAF incubation in the Tris pH 7.2 buffer was 20 min with 1 $\mathrm{mg} / \mathrm{mL}$ HLS9. The sample preparation procedure following incubation was identical to the HLS9 activity assay described above.

\section{Effect of CES1 variant G143E on TAF hydrolysis}

Another in vitro incubation study was conducted to assess the effect of the CES1 nonsynonymous variant G143E on TAF hydrolysis. TAF $(100 \mu \mathrm{M})$ was incubated with the $S 9$ fractions $(0.15 \mathrm{mg}$ protein $/ \mathrm{mL}$ ) of Flp-In HEK 293 cells stably transfected with wild-type CES1, the CES1 variant G143E, or blank vector at $37^{\circ} \mathrm{C}$ for $30 \mathrm{~min}$. CES1 protein levels are comparable between the wild-type CES1 and the G143E variant cell lines (Zhu et al., 2008). The reactions were terminated by adding a two-fold volume of $\mathrm{ACN}$ containing the internal standard AFV $(20 \mu \mathrm{M})$. The samples were then vortexed for $5 \mathrm{~min}$ and centrifuged at $17,000 \mathrm{rpm}$ at $4^{\circ} \mathrm{C}$ for $10 \mathrm{~min}$ to remove the precipitated proteins. The resulting 
supernatant was collected for analysis of the formed TFV using an LC-MS/MS assay.

\section{LC-MS/MS analysis of TAF and TFV and CES1 and CatA protein concentrations in HLS9}

TAF and TFV were quantified based on the previously reported methods with some modifications (King et al., 2006; Avataneo et al., 2020). The methods were detailed in Supplemental Materials. A proteomics study was conducted to quantify the proteomes of the pooled HLS9 using a DIA-MS-based proteomic method established in our laboratory (Wang et al., 2020). The study was carried out on a TripleTOF 5600 plus mass spectrometer (AB Sciex, Framingham, MA) coupled with an Eksigent 2D plus LC system (Eksigent Technologies, Dublin, CA). The proteomics data were analyzed using the Spectronaut Pulsar software (version 11.0; Biognosys AG, Schlieren, Switzerland) with its internal reference spectral library "Human - Liver (fractionated)". The absolute protein expressions of the hydrolases of interest were calculated using the MS2-based DIA-TPA algorithm (He et al., 2019).

\section{Data Analysis}

GraphPad Prism version 8.3.0 (GraphPad Software, San Diego, CA) was used for generating graphs. IBM SPSS 28.0 (IBM Corp, Armonk, NY, USA) was used for statistical analysis. Student's $t$-test was used to analyze the differences in TAF hydrolysis activity between two $\mathrm{pH}$ conditions. The relative contributions of CatA and CES1 to TAF hydrolysis in HLS9 were calculated by multiplying the TAF hydrolytic activity of each purified enzyme with its protein expression level in HLS9. The analysis of variance (ANOVA) was used to analyze the differences in TAF hydrolysis between groups incubated with various concentrations of CES1 or CatA inhibitors and different TAF hydrolytic rates following the incubation with the vector, wild type CES1, and the G143E variant cell S9 fractions. A $P$-value less than 0.05 was considered statistically significant. 


\section{Results}

\section{CatA contributed more to TAF hydrolysis in HLS9 than CES1}

The activity of rhCatA and rhCES1 on TAF hydrolysis are summarized in Table 1. rhCatA activity was approximately 1,000-fold higher than rhCES1. Our DIA-based proteomics analysis showed that the protein concentrations of CatA and CES1 were 0.082 and $17.7 \mu \mathrm{g}$ enzyme/mg total protein, respectively, in the pooled HLS9. We estimated the contributions of CatA and CES1 to TAF hydrolysis in HLS9 by multiplying their activity with their protein abundance in HLS9. The results indicate that the contribution of CatA to TAF hydrolysis in HLS9 was approximately 3 to 5-fold of that of CES1 when TAF concentrations were 10-100 $\mu \mathrm{M}$ (Table 1).

\section{Activity of rhCatA and rhCES1 and HLS9 on hydrolyzing TAF was affected by $\mathrm{pH}$}

A significant $\mathrm{pH}$-dependent effect was observed on TAF hydrolysis following incubation with rhCES1, rhCatA, and HLS9 (Figure 2). rhCES1 activity in its optimal $\mathrm{pH}$ condition $(\mathrm{pH} 7.2)$ was about 4-fold higher than that at $\mathrm{pH} 5.2(6.10 \pm$ 1.11 vs. $1.19 \pm 0.74 \mathrm{pmol} / \mathrm{min} / \mu \mathrm{g}$ protein, $\mathrm{n}=3, P<0.01$, Figure $2 \mathrm{a})$. On the contrary, the activity of rhCatA at pH 5.2 was over 1 -fold higher than its activity at $\mathrm{pH} 7.2(2,742.45 \pm 185.48$ vs. $1,187.99 \pm 111.80 \mathrm{pmol} / \mathrm{min} / \mu \mathrm{g}$ protein, $\mathrm{n}=3, P<$ 0.01 , Figure $2 b$ ). Moreover, TAF hydrolysis activity of HLS9 measured in the MES

pH 5.2 buffer was about 3-fold higher than that in the Tris pH 7.2 buffer (1904.20 \pm $17.38 \mathrm{vs} .480 .58 \pm 75.08 \mathrm{pmol} / \mathrm{min} / \mathrm{mg}$ protein, $\mathrm{n}=3, P<0.01$, Figure $3 \mathrm{c})$. TAF was stable in both MES pH 5.2 and Tris $\mathrm{pH} 7.2$ blank buffers at $37^{\circ} \mathrm{C}$ for $30 \mathrm{~min}$.

\section{Effects of CES1 and CatA inhibitors on TAF hydrolysis in HLS9}

To confirm the role of CatA and CES1 in hydrolyzing TAF in human livers, we further investigated the effects of the CatA inhibitor telaprevir and the CES1 inhibitor BNPP on TAF hydrolysis in HLS9. As shown in Figure 3. in the pH 5.2 condition, BNPP $(1-50 \mu \mathrm{M})$ showed an inappreciable effect on TAF hydrolysis by 
HLS9, while telaprevir at only $0.5 \mu \mathrm{M}$ could significantly inhibit TAF hydrolysis $(P<$ 0.01). Of note, telaprevir at $50 \mu \mathrm{M}$ could nearly abolish the TAF hydrolysis activity in HLS9. In the $\mathrm{pH} 7.2$ condition, telaprevir $(0.5-50 \mu \mathrm{M})$ significantly inhibited the TAF hydrolysis in HLS9, while for BNPP, no significant inhibitory effect on TAF hydrolysis was observed even when the BNPP concentration reached $50 \mu \mathrm{M}(P>$ $0.05)$.

\section{CES1-mediated TAF hydrolysis was significantly impaired by the genetic polymorphism G143E}

TAF was incubated with the S9 fractions of Flp-In HEK 293 cells stably expressing wild-type CES1 and the G143E variant. The S9 fractions of the wild-type CES1 cells efficiently hydrolyzed TAF to the intermediate metabolite TFV $(2.45 \pm 0.30$ $\mathrm{nmol} / \mathrm{mg} \mathrm{S9} \mathrm{protein} / \mathrm{min})$. The catalytic activity was reduced by $64 \%$ in the S9 fractions of both the G143E and the blank vector-transfected cells (Figure 4), suggesting that the G143E is a loss-of-function variant for CES1-mediated TAF hydrolysis. 


\section{Discussion}

Identifying key hepatic enzymes in TAF activation is essential to understand the interindividual variability in the PK and anti-HBV efficacy of TAF therapy. A previous study suggested that CES1 was the primary enzyme responsible for TAF hydrolysis in the human liver (Murakami et al., 2015), and the information has been included in the FDA label of TAF (Vemlidy $\left.{ }^{\circledR}\right)$. This conclusion was based on an in vitro inhibitory study in primary human hepatocytes (Murakami et al., 2015), which showed that the CatA inhibitors telaprevir and boceprevir did not significantly affect TAF activation, whereas the CES1 inhibitor BNPP significantly reduced the formation of the TAF active metabolite TFV-DP. Birkus et al. reported that six hydrolases, namely porcine liver carboxylesterase (a close homolog of human CES1 (Lange et al., 2001)), CatA, leukocyte elastase, pancreatic elastase 1 , proteinase 3 , and cathepsin $\mathrm{H}$, out of the 16 tested enzymes showed catalytic activity towards TAF hydrolysis (Birkus et al., 2008b; Birkus et al., 2016). Specifically, CatA exhibited the highest hydrolytic activity $(31,000 \mathrm{pmol} / \mathrm{\mu g}$ enzyme/min), which was approximately 35 - to 1,148-fold higher than other hydrolases, when TAF was incubated at a single concentration of $100 \mu \mathrm{M}$. In the present study, the rhCatA activity was found to be $33,918 \pm 1,185 \mathrm{pmol} / / / \mathrm{\mu g}$ enzyme/min when TAF concentration was $100 \mu \mathrm{M}$. Of note, Birkus and colleagues performed the CatA activity assay at $\mathrm{pH} 6.5$ while we conducted the CatA activity study at pH 5.2 to mimic the acidic condition in the lysosomes. The enzyme manufacture also recommended using an acidic reaction buffer ( $\sim \mathrm{pH} 5.5)$ to determine the CatA catalytic activity. One of the aims of this study was to determine the contributions of CES1 and CatA the TAF hydrolysis in the liver based on the hepatic protein levels and the enzymatic efficiencies on catalyzing TAF hydrolysis of the two enzymes. Our DIA proteomics analysis showed that the protein abundances of CES1 and CatA in the pooled HLS9 were 17.7 and 0.082 $\mu \mathrm{g} / \mathrm{mg} \mathrm{HLS} 9$ protein, respectively. A recent study reported that the CES1 and CatA were $34 \pm 1$ and $0.23 \pm 0.11 \mu \mathrm{g} / \mathrm{mg}$ total protein, respectively, in pooled HLS9 (Li et al., 2021). The differences may be due to the different HLS9 resources and the protein quantification methods used in the two studies (i.e., DIA 
proteomics vs. Western Blot). In addition, a previous proteomics study profiled the proteomes of primary hepatocytes from six donors and found that CES1 and CatA were $13.7 \pm 3.0$ and $0.059 \pm 0.014 \mu \mathrm{g} / \mathrm{mg}$ total protein, respectively (Wiśniewski et al., 2016). Interestingly, despite the slight differences in the absolute values, all studies demonstrated that hepatic CES1 protein expression was approximately 200 -fold of the CatA protein level in the human liver. Our study revealed that the activity of CatA on hydrolyzing TAF was approximately 1,000-fold higher than that of CES1 when TAF concentrations were within 10 and $100 \mu \mathrm{M}$ (Table 1). Taking both activity and protein abundance into consideration, we estimated that the contribution of CatA to TAF hydrolysis in HLS9 was about 3 to 5 -fold of that of CES1. Of note, although hepatic TAF concentration in humans is unknown, plasma TAF mean $\mathrm{C}_{\max }$ was found to be approximately $4 \mu \mathrm{M}$ in patients who received a single dose of $120 \mathrm{mg}$ TAF (Markowitz et al., 2014); thus, the TAF concentrations utilized in the in vitro incubation study are clinically relevant. Birkus et al. reported that, besides CES1 and CatA, leukocyte elastase, pancreatic elastase 1 , proteinase 3 , and cathepsin $\mathrm{H}$ also showed catalytic activity towards TAF hydrolysis (Birkus et al., 2008b; Birkus et al., 2016). Nevertheless, their contributions appear to be negligible due to their very low activity as well as very low protein expression in the human liver.

Given that the subcellular locations of CatA and CES1 are different (i.e., CatA: lysosome ( $\mathrm{pH} \sim 4.7)$ and $\mathrm{CES1}$ : endoplasmic reticulum lumen/cytoplasm $(\mathrm{pH}$ 7.1 7.4) (Casey et al., 2010), the in vitro incubation studies were conducted in two different buffers: MES buffer ( $\mathrm{pH}$ 5.2) and Tris buffer ( $\mathrm{pH}$ 7.2). A significant $\mathrm{pH}$-dependent effect was observed for the activity of both CES1 and CatA. It is generally accepted that CatA is an acidic $\mathrm{pH}$-dependent serine protease, and the acidic condition is critical for its catalytic functions. For example, chloroquine, a common agent capable of increasing lysosomal $\mathrm{pH}$, was found to inhibit the intracellular activation of GS-9191, another ester prodrug hydrolyzed by CatA (Birkus et al., 2011). The activity of CES1 was decreased at pH 5.2 compared with that at $\mathrm{pH} 7.2$, which was consistent with the previous report that the CES1 activity was stable in pH 6.5-7.5 (Inoue et al., 1980). Thus, the activity measured 
in $\mathrm{pH} 5.2$ for rhCatA and $\mathrm{pH} 7.2$ for rhCES1 should reasonably reflect their in situ physiological catalytic activities.

We conducted an in vitro inhibition study to further elucidate the involvement of CatA and CES1 in hepatic TAF hydrolysis. It has been well documented that telaprevir and BNPP are potent CatA and CES1 inhibitors, respectively (Murakami et al., 2010; Li et al., 2021). Moreover, at the tested concentrations (1 $50 \mu \mathrm{M})$, telaprevir did not impact the CES1 activity, whereas BNPP had no effect on the activity of CatA (Murakami et al., 2010; Li et al., 2021). Telaprevir at $0.5 \mu \mathrm{M}$ could markedly inhibit TAF hydrolysis in HLS9 at pH 5.2 and $\mathrm{pH}$ 7.2, while BNPP only showed a weak inhibitory effect at $50 \mu \mathrm{M}$ under the $\mathrm{pH} 7.2$ condition. It should be noted that $50 \mu \mathrm{M}$ BNPP could fully impair CES1 activity (Fujiyama et al., 2010); however, a significant portion of TAF hydrolysis activity remained intact after incubation with $50 \mu \mathrm{M}$ BNPP. Thus, the inhibitory study further supports a more significant role of CatA in hydrolyzing TAF in HLS9 relative to CES1.

Interestingly, Murakami et al. did not observe a significant inhibitory effect of the protease inhibitors telaprevir and boceprevir on TAF metabolism in primary human hepatocytes (Murakami et al., 2015). This discrepancy might be due to the limited intracellular accumulation of these protease inhibitors since both telaprevir and boceprevir are the substrates of the efflux transporter P-gp, which is highly expressed in hepatocytes (Chu et al., 2013; Fujita et al., 2013; Weiss et al., 2014; Murakami et al., 2015). The lack of inhibitory effects of telaprevir and boceprevir in primary human hepatocytes could also be caused by the potential reduction of CatA expression in hepatocytes under in vitro culture conditions (Richert et al., 2006). In the present study, we performed an in vitro inhibition study using HLS9 samples instead of hepatocytes to avoid the abovementioned two potential limitations and demonstrated a significant inhibitory effect of telaprevir on hepatic TAF hydrolysis.

Taken together, our conclusion that CatA may play a more important role than CES1 in hydrolyzing TAF in the liver is supported by the following three observations: 1) a greater contribution of CatA to TAF hydrolysis in HLS9 than 
CES1 based on the activity data and the hepatic protein abundances of the two enzymes; 2) a substantial increase of TAF hydrolysis in HLS9 when the incubation study was conducted at the optimal $\mathrm{pH}$ for CatA (i.e., pH 5.2); 3) the CatA inhibitor telaprevir exhibited a more potent inhibitory effect on TAF hydrolysis in HLS9 than the CES1 inhibitor BNPP.

The CES1 genetic polymorphism G143E is a loss-of-function variant for many CES1 substrates (Her and Zhu, 2020). Its minor allele frequencies are approximately 3.7\%, 2.0\%, and 4.3\% in Caucasian, African American, and Hispanic populations, respectively, but the variant is extremely rare in Asian populations (Zhu et al., 2008; Suzaki et al., 2013). The G143E variant abolishes CES1 catalytic activity and subsequently affect the PK and PD of various CES1 substrate medications, such as methylphenidate, clopidogrel, dabigatran etexilate, and angiotensin-converting enzyme inhibitors (Zhu et al., 2008; Lewis et al., 2013; Tarkiainen et al., 2015a; Tarkiainen et al., 2015b; Shi et al., 2016a; Shi et al., 2016b; Shi et al., 2016c; Wang et al., 2016; Stage et al., 2017). To investigate the impact of the CES1 genetic polymorphism G143E on the hydrolysis of TAF, we conducted a TAF incubation study using Flp-In HEK 293 cells stably expressing wild-type CES1 and the G143E variant. We found that the G143E variant markedly reduced TAF hydrolysis to a level similar to that in the blank vector-transfected cells (Figure 4), indicating that the G143E is a loss-of-function variant for the CES1-mediated TAF hydrolysis. However, given that CES1 was estimated to only account for a small portion of the TAF hydrolysis in the liver, the impact of the G143E variant on hepatic TAF activation is expected to be less significant compared with its impact on other selective CES1 substrates, such as methylphenidate and clopidogrel (Zhu et al., 2008; Zhu et al., 2013). We also observed considerable TAF hydrolysis activity in the G143E and the blank vector cells (Figure 4), which is likely attributed to CatA.

This study has several potential limitations. One limitation is that, due to the limited TAF solubility, we were unable to conduct a kinetic study to determine the kinetic parameters (i.e., $K_{m}$ and $V_{\max }$ ) of the two enzymes because of the inability to include high substrate concentrations at levels that could saturate the enzymes. 
Another limitation is that the estimated contributions of CatA and CES1 to hepatic TAF hydrolysis are based on the assumption that CatA and CES1 proteins found in HLS9 are reflective of their levels in the liver. CES1 is present in both endoplasmic reticulum lumen and cytoplasm, and CatA is exclusively expressed in the lysosomes. It has been reported that the HLS9 preparation could not completely extract the endoplasmic reticulum luminal fractions and the lysosomes (Xu et al., 2018). However, the recovery rates of endoplasmic reticulum lumen ( $85-95 \%)$ and lysosomal lumen ( 85\%) in the S9 fractions were comparable (Xu et al., 2018), and thus, the incomplete extraction should not affect our estimation of the relative contributions of CatA and CES1 to hepatic TAF hydrolysis. A further limitation of this study is that the HLS9 system is unable to evaluate the effect of the partition of a drug in cell organelles (e.g., lysosomes) on drug metabolism. Since CatA is a lysosomal protein, TAF needs to enter the lysosomes to be hydrolyzed by CatA. Although it remains unexplored regarding how efficient and to what extent TAF can be accumulated in the lysosomes, TAF appears to readily enter into the lysosomes according to a previous report, which showed that TAF was effectively hydrolyzed by CatA in peripheral blood mononuclear (PBMC) cells (Birkus et al., 2007). Moreover, lysosomes have been identified as the organelle involving TAF hydrolysis in MT-2 and PBMC cells using organelle marker assays (Birkus et al., 2008a).

In sum, our study suggested that CatA may play a major role in hydrolyzing TAF in the human liver. For the first time, the activities of CES1, CatA, and HLS9 on TAF hydrolysis were found to be highly $\mathrm{pH}$-dependent, highlighting the importance of using appropriate $\mathrm{pH}$ in in vitro drug metabolism studies. Moreover, we showed that the CES1 genetic polymorphism G143E is a loss-of-function variant for CES1-mediated TAF hydrolysis. However, we expect that the impact of this variant on the anti-HBV therapy of TAF is modest because of the significant involvement of CatA in hepatic TAF hydrolysis. Further investigations are warranted to confirm the significance of CatA in activating TAF in human livers using in vivo models. 


\section{Authorship Contributions}

Participated in research design: Jiapeng Li, Jian Shi, and Hao-Jie Zhu.

Conducted experiments: Jiapeng Li, Jian Shi, Lana Tran, Jingcheng Xiao.

Performed data analysis: Jiapeng Li, Jian Shi, Lana Tran, Xinwen Wang,

Jingcheng Xiao, and Hao-Jie Zhu.

Wrote or contributed to the writing of the manuscript: Jiapeng Li, Jian Shi, Lana Tran, Xinwen Wang, and Hao-Jie Zhu.

\section{Conflict of Interest}

The authors have declared no conflict of interest. Lana Tran's affiliation at the time of involvement is with the University of Michigan College of Pharmacy and therefore declares no conflict of interest. 


\section{References}

Agarwal K, Fung SK, Nguyen TT, Cheng W, Sicard E, Ryder SD, Flaherty JF, Lawson E, Zhao S, Subramanian GM, McHutchison JG, Gane EJ, and Foster GR (2015) Twenty-eight day safety, antiviral activity, and pharmacokinetics of tenofovir alafenamide for treatment of chronic hepatitis B infection. J Hepatol 62:533-540.

Avataneo V, de Nicolò A, Cusato J, Antonucci M, Manca A, Palermiti A, Waitt C, Walimbwa S, Lamorde M, di Perri G, and D'Avolio A (2020) Development and validation of a UHPLC-MS/MS method for quantification of the prodrug remdesivir and its metabolite GS-441524: a tool for clinical pharmacokinetics of SARS-CoV-2/COVID-19 and Ebola virus disease. Journal of Antimicrobial Chemotherapy 75:1772-1777.

Babusis D, Phan TK, Lee WA, Watkins WJ, and Ray AS (2013) Mechanism for effective lymphoid cell and tissue loading following oral administration of nucleotide prodrug GS-7340. Molecular pharmaceutics 10:459-466.

Bedimo R, Rosenblatt L, and Myers J (2016) Systematic review of renal and bone safety of the antiretroviral regimen efavirenz, emtricitabine, and tenofovir disoproxil fumarate in patients with HIV infection. HIV clinical trials 17:246-266.

Birkus G, Bam RA, Willkom M, Frey CR, Tsai L, Stray KM, Yant SR, and Cihlar T (2016) Intracellular Activation of Tenofovir Alafenamide and the Effect of Viral and Host Protease Inhibitors. Antimicrob Agents Chemother 60:316-322.

Birkus G, Kutty N, Frey CR, Shribata R, Chou T, Wagner C, McDermott M, and Cihlar T (2011) Role of Cathepsin A and Lysosomes in the Intracellular Activation of Novel Antipapillomavirus Agent GS-9191. 55:2166-2173.

Birkus G, Kutty N, He G-X, Mulato A, Lee W, McDermott M, and Cihlar T (2008a) Activation of 9-[(R)-2-[[(S)-[[(S)-1-(Isopropoxycarbonyl) ethyl] amino] phenoxyphosphinyl]-methoxy] propyl] adenine (GS-7340) and other tenofovir phosphonoamidate prodrugs by human proteases. Molecular pharmacology 74:92-100.

Birkus G, Kutty N, He GX, Mulato A, Lee W, McDermott M, and Cihlar T (2008b) Activation of 9-[(R)-2-[[(S)-[[(S)-1-(Isopropoxycarbonyl)ethyl]amino] phenoxyphosphinyl]-methoxy]propyl]adenine (GS-7340) and other tenofovir phosphonoamidate prodrugs by human proteases. Mol Pharmacol 74:92-100.

Birkus G, Wang R, Liu X, Kutty N, MacArthur H, Cihlar T, Gibbs C, Swaminathan S, Lee W, and McDermott M (2007) Cathepsin A is the major hydrolase catalyzing the intracellular hydrolysis of the antiretroviral nucleotide phosphonoamidate prodrugs GS-7340 and GS-9131. Antimicrob Agents Chemother 51:543-550.

Buti M, Tsai N, Petersen J, Flisiak R, Gurel S, Krastev Z, Aguilar Schall R, Flaherty JF, Martins EB, Charuworn P, Kitrinos KM, Subramanian GM, Gane E, and Marcellin P (2015) Seven-year efficacy and safety of treatment with tenofovir disoproxil fumarate for chronic hepatitis B virus infection. Digestive diseases and sciences 60:1457-1464.

Casey JR, Grinstein S, and Orlowski J (2010) Sensors and regulators of intracellular $\mathrm{pH}$. Nature Reviews Molecular Cell Biology 11:50-61.

Chu X, Cai X, Cui D, Tang C, Ghosal A, Chan G, Green MD, Kuo Y, Liang Y, Maciolek CM, Palamanda J, Evers R, and Prueksaritanont T (2013) In vitro assessment of drug-drug interaction potential of boceprevir associated with drug metabolizing 
enzymes and transporters. Drug metabolism and disposition: the biological fate of chemicals 41:668-681.

Cooper RD, Wiebe N, Smith N, Keiser P, Naicker S, and Tonelli M (2010) Systematic review and meta-analysis: renal safety of tenofovir disoproxil fumarate in HIV-infected patients. Clinical infectious diseases : an official publication of the Infectious Diseases Society of America 51:496-505.

Custodio JM, Fordyce M, Garner W, Vimal M, Ling KH, Kearney BP, and Ramanathan S (2016) Pharmacokinetics and Safety of Tenofovir Alafenamide in HIV-Uninfected Subjects with Severe Renal Impairment. Antimicrob Agents Chemother 60:5135-5140.

Fujita Y, Noguchi K, Suzuki T, Katayama K, and Sugimoto Y (2013) Biochemical interaction of anti-HCV telaprevir with the ABC transporters P-glycoprotein and breast cancer resistance protein. BMC research notes 6:445.

Fujiyama N, Miura M, Kato S, Sone T, Isobe M, and Satoh S (2010) Involvement of carboxylesterase 1 and 2 in the hydrolysis of mycophenolate mofetil. Drug metabolism and disposition: the biological fate of chemicals 38:2210-2217.

He B, Shi J, Wang X, Jiang H, and Zhu HJ (2019) Label-free absolute protein quantification with data-independent acquisition. J Proteomics 200:51-59.

Henningsson A, Marsh S, Loos WJ, Karlsson MO, Garsa A, Mross K, Mielke S, Viganò L, Locatelli A, and Verweij JJCCR (2005) Association of CYP2C8, CYP3A4, CYP3A5, and ABCB1 polymorphisms with the pharmacokinetics of paclitaxel. 11:8097-8104.

Her L and Zhu HJ (2020) Carboxylesterase 1 and Precision Pharmacotherapy: Pharmacogenetics and Nongenetic Regulators. Drug metabolism and disposition: the biological fate of chemicals 48:230-244.

Imai T (2006) Human carboxylesterase isozymes: catalytic properties and rational drug design. Drug metabolism and pharmacokinetics 21:173-185.

Inoue M, Morikawa M, Tsuboi M, Ito Y, and Sugiura M (1980) COMPARATIVE STUDY OF HUMAN INTESTINAL AND HEPATIC ESTERASES AS RELATED TO ENZYMATIC PROPERTIES AND HYDROLIZING ACTIVITY FOR ESTER-TYPE DRUGS. The Japanese Journal of Pharmacology 30:529-535.

Kearney BP, Flaherty JF, and Shah J (2004) Tenofovir disoproxil fumarate: clinical pharmacology and pharmacokinetics. Clinical pharmacokinetics 43:595-612.

King T, Bushman L, Kiser J, Anderson PL, Ray M, Delahunty T, and Fletcher CV (2006) Liquid chromatography-tandem mass spectrometric determination of tenofovir-diphosphate in human peripheral blood mononuclear cells. $J$ Chromatogr B Analyt Technol Biomed Life Sci 843:147-156.

Lange S, Musidlowska A, Schmidt-Dannert C, Schmitt J, and Bornscheuer UT (2001) Cloning, functional expression, and characterization of recombinant pig liver esterase. Chembiochem : a European journal of chemical biology 2:576-582.

Lewis JP, Horenstein RB, Ryan K, O'Connell JR, Gibson Q, Mitchell BD, Tanner K, Chai S, Bliden KP, Tantry US, Peer CJ, Figg WD, Spencer SD, Pacanowski MA, Gurbel PA, and Shuldiner AR (2013) The functional G143E variant of carboxylesterase 1 is associated with increased clopidogrel active metabolite levels and greater clopidogrel response. Pharmacogenetics and genomics 23:1-8. 
Li R, Liclican A, Xu Y, Pitts J, Niu C, Zhang J, Kim C, Zhao X, Soohoo D, Babusis D, Yue Q, Ma B, Murray Bernard P, Subramanian R, Xie X, Zou J, Bilello John P, Li L, Schultz Brian E, Sakowicz R, Smith Bill J, Shi P-Y, Murakami E, and Feng Joy Y (2021) Key Metabolic Enzymes Involved in Remdesivir Activation in Human Lung Cells. Antimicrobial Agents and Chemotherapy 0:AAC.00602-00621.

Markowitz M, Zolopa A, Squires K, Ruane P, Coakley D, Kearney B, Zhong L, Wulfsohn M, Miller MD, and Lee WA (2014) Phase I/II study of the pharmacokinetics, safety and antiretroviral activity of tenofovir alafenamide, a new prodrug of the HIV reverse transcriptase inhibitor tenofovir, in HIV-infected adults. The Journal of antimicrobial chemotherapy 69:1362-1369.

Murakami E, Tolstykh T, Bao H, Niu C, Steuer HMM, Bao D, Chang W, Espiritu C, Bansal S, and Lam AM (2010) Mechanism of activation of PSI-7851 and its diastereoisomer PSI-7977. Journal of Biological Chemistry 285:34337-34347.

Murakami E, Wang T, Park Y, Hao J, Lepist EI, Babusis D, and Ray AS (2015) Implications of efficient hepatic delivery by tenofovir alafenamide (GS-7340) for hepatitis B virus therapy. Antimicrob Agents Chemother 59:3563-3569.

Rautio J, Kumpulainen H, Heimbach T, Oliyai R, Oh D, Jarvinen T, and Savolainen J (2008) Prodrugs: design and clinical applications. Nat Rev Drug Discov 7:255-270.

Richert L, Liguori MJ, Abadie C, Heyd B, Mantion G, Halkic N, and Waring JF (2006) Gene expression in human hepatocytes in suspension after isolation is similar to the liver of origin, is not affected by hepatocyte cold storage and cryopreservation, but is strongly changed after hepatocyte plating. Drug metabolism and disposition: the biological fate of chemicals 34:870-879.

Shi J, Wang X, Eyler RF, Liang Y, Liu L, Mueller BA, and Zhu HJ (2016a) Association of Oseltamivir Activation with Gender and Carboxylesterase 1 Genetic Polymorphisms. Basic Clin Pharmacol Toxicol 119:555-561.

Shi J, Wang X, Nguyen J, Wu AH, Bleske BE, and Zhu HJ (2016b) Sacubitril Is Selectively Activated by Carboxylesterase 1 (CES1) in the Liver and the Activation Is Affected by CES1 Genetic Variation. Drug metabolism and disposition: the biological fate of chemicals 44:554-559.

Shi J, Wang X, Nguyen JH, Bleske BE, Liang Y, Liu L, and Zhu HJ (2016c) Dabigatran etexilate activation is affected by the CES1 genetic polymorphism G143E (rs71647871) and gender. Biochem Pharmacol 119:76-84.

Stage C, Jurgens G, Guski LS, Thomsen R, Bjerre D, Ferrero-Miliani L, Lyauk YK, Rasmussen HB, Dalhoff K, and Consortium I (2017) The impact of CES1 genotypes on the pharmacokinetics of methylphenidate in healthy Danish subjects. British journal of clinical pharmacology 83:1506-1514.

Suzaki Y, Uemura N, Hosokawa M, and Ohashi KJEjocp (2013) Gly143Glu polymorphism of the human carboxylesterase1 gene in an Asian population. 69:735.

Tarkiainen EK, Holmberg MT, Tornio A, Neuvonen M, Neuvonen PJ, Backman JT, and Niemi M (2015a) Carboxylesterase 1 c.428G>A single nucleotide variation increases the antiplatelet effects of clopidogrel by reducing its hydrolysis in humans. Clinical pharmacology and therapeutics 97:650-658.

Tarkiainen EK, Tornio A, Holmberg MT, Launiainen T, Neuvonen PJ, Backman JT, and 
Niemi M (2015b) Effect of carboxylesterase 1 c.428G > A single nucleotide variation on the pharmacokinetics of quinapril and enalapril. British journal of clinical pharmacology 80:1131-1138.

Terrault NA, Lok ASF, McMahon BJ, Chang KM, Hwang JP, Jonas MM, Brown RS, Jr., Bzowej NH, and Wong JB (2018) Update on prevention, diagnosis, and treatment of chronic hepatitis B: AASLD 2018 hepatitis B guidance. Hepatology 67:1560-1599.

Trepo C, Chan HL, and Lok A (2014) Hepatitis B virus infection. Lancet 384:2053-2063.

Wang X, He B, Shi J, Li Q, and Zhu HJ (2020) Comparative Proteomics Analysis of Human Liver Microsomes and S9 Fractions. Drug metabolism and disposition: the biological fate of chemicals 48:31-40.

Wang X, Wang G, Shi J, Aa J, Comas R, Liang Y, and Zhu HJ (2016) CES1 genetic variation affects the activation of angiotensin-converting enzyme inhibitors. Pharmacogenomics J 16:220-230.

Weiss J, Becker JP, and Haefeli WE (2014) Telaprevir is a substrate and moderate inhibitor of P-glycoprotein, a strong inductor of ABCG2, but not an activator of PXR in vitro. Int J Antimicrob Agents 43:184-188.

Wiśniewski JR, Vildhede A, Norén A, and Artursson P (2016) In-depth quantitative analysis and comparison of the human hepatocyte and hepatoma cell line HepG2 proteomes. Journal of Proteomics 136:234-247.

Xu M, Saxena N, Vrana M, Zhang H, Kumar V, Billington S, Khojasteh C, Heyward S, Unadkat JD, and Prasad B (2018) Targeted LC-MS/MS Proteomics-Based Strategy To Characterize in Vitro Models Used in Drug Metabolism and Transport Studies. Analytical chemistry 90:11873-11882.

Zhu HJ, Patrick KS, Yuan HJ, Wang JS, Donovan JL, DeVane CL, Malcolm R, Johnson JA, Youngblood GL, Sweet DH, Langaee TY, and Markowitz JS (2008) Two CES1 gene mutations lead to dysfunctional carboxylesterase 1 activity in man: clinical significance and molecular basis. Am J Hum Genet 82:1241-1248.

Zhu HJ, Wang X, Gawronski BE, Brinda BJ, Angiolillo DJ, and Markowitz JS (2013) Carboxylesterase 1 as a determinant of clopidogrel metabolism and activation. $J$ Pharmacol Exp Ther 344:665-672. 


\section{Footnotes}

This work was partially supported by the National Institutes of Health National Heart, Lung, and Blood Institute [R01 HL126969, Hao-Jie Zhu], the Eunice Kennedy Shriver National Institute of Child Health and Human Development [R01 HD093612, John S. Markowitz and Hao-Jie Zhu]. 


\section{Figure legends}

Figure 1. Activation pathway of TAF in the human liver. TAF was first hydrolyzed to tenofovir-alanine (TFV-Ala) by hepatic hydrolases, then converted to TFV via histidine triad nucleotide-binding protein 1 (HINT1)-mediated hydrolysis. TFV was further phosphorylated to the active metabolite tenofovir diphosphate (TFV-DP) by native kinases.

Figure 2. TAF hydrolysis activity of rhCES1 (a), rhCatA (b), and HLS9 (c) in MES pH 5.2 assay buffer and Tris $\mathrm{pH} 7.2$ buffer. $40 \mathrm{ng} / \mu \mathrm{L}$ rhCES1, $0.25 \mathrm{ng} / \mu \mathrm{L}$ rhCatA, and $0.5 \mathrm{mg} / \mathrm{mLHLS} 9$ were incubated with $20 \mu \mathrm{M} \mathrm{TAF}$ at $37^{\circ} \mathrm{C}$ for $20 \mathrm{~min}, 10 \mathrm{~min}$, and $15 \mathrm{~min}$, respectively. Bars are mean values ( \pm S.D.) of at least three independent experiments $(\mathrm{n} \geq 3)$. ${ }^{* *} P<0.01$.

Figure 3. Effect of telaprevir and BNPP on TAF hydrolysis in HLS9 in MES pH 5.2 assay buffer (a) and Tris pH 7.2 buffer (b). Data are shown as the remaining TAF (mean \pm S.D., $\mathrm{n}=3$ ) following incubation. ${ }^{* \star} P<0.01$ compared to the vehicle control. In the MES pH 5.2 assay buffer, $20 \mu \mathrm{M}$ TAF were incubated with 0.5 $\mathrm{mg} / \mathrm{mL} \mathrm{HLS9}$ at $37^{\circ} \mathrm{C}$ for $15 \mathrm{~min}$; in the Tris $\mathrm{pH} 7.5$ buffer, $20 \mu \mathrm{M}$ TAF were incubated with $1 \mathrm{mg} / \mathrm{mL} \mathrm{HLS} 9$ at $37^{\circ} \mathrm{C}$ for $20 \mathrm{~min}$.

Figure 4. Effect of the CES1 genetic polymorphism G143E on TAF activation in the S9 fractions of the transfected Flp-In HEK 293 cells. Data are shown as the formation rates of TFV (mean \pm S.D., $n=3$ ). ${ }^{*} P<0.05,{ }^{* *} P<0.01$ compared to the wild-type HEK 293 cells. 


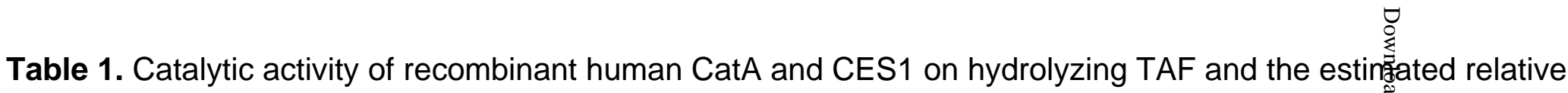
contributions of CatA and CES1 to TAF hydrolysis in HLS9.

\begin{tabular}{|c|c|c|c|c|c|c|}
\hline$\overline{\mathrm{TAF}}(\mu \mathrm{M})$ & 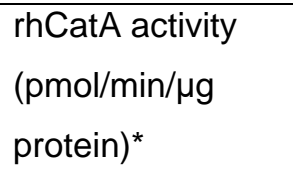 & 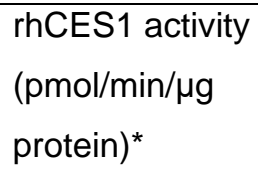 & $\begin{array}{l}\text { rhCatA to rhCES1 } \\
\text { Activity ratio }\end{array}$ & $\begin{array}{l}\text { CatA abundance } \\
\text { in HLS9 ( } \mu \mathrm{g} / \mathrm{mg} \\
\text { total protein) }\end{array}$ & 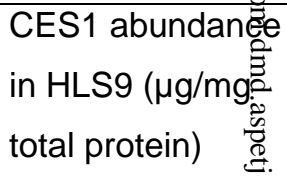 & $\begin{array}{l}\text { Contribution to TAF } \\
\text { hydrolysis in HLS9 } \\
\text { (CatA:CES1) }\end{array}$ \\
\hline 10 & $3328.7 \pm 162.1$ & $4.8 \pm 0.4$ & $693: 1$ & \multirow{4}{*}{0.082} & \multirow{4}{*}{17.70} & $3.2: 1$ \\
\hline 20 & $6817.3 \pm 1030.5$ & $6.7 \pm 1.1$ & $1048: 1$ & & & $4.9: 1$ \\
\hline 50 & $16221.0 \pm 2564.3$ & $16.2 \pm 4.0$ & $1061: 1$ & & & $4.9: 1$ \\
\hline 100 & $33918.0 \pm 6175.3$ & $28.6 \pm 4.2$ & $1203: 1$ & & & $5.6: 1$ \\
\hline Data wer & ined from three $\mathrm{i}$ & endent experin & $=3)$ & & 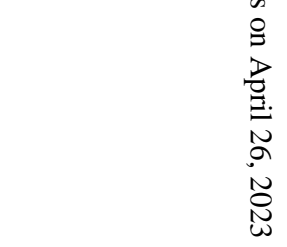 & \\
\hline
\end{tabular}




\section{Figure 1}

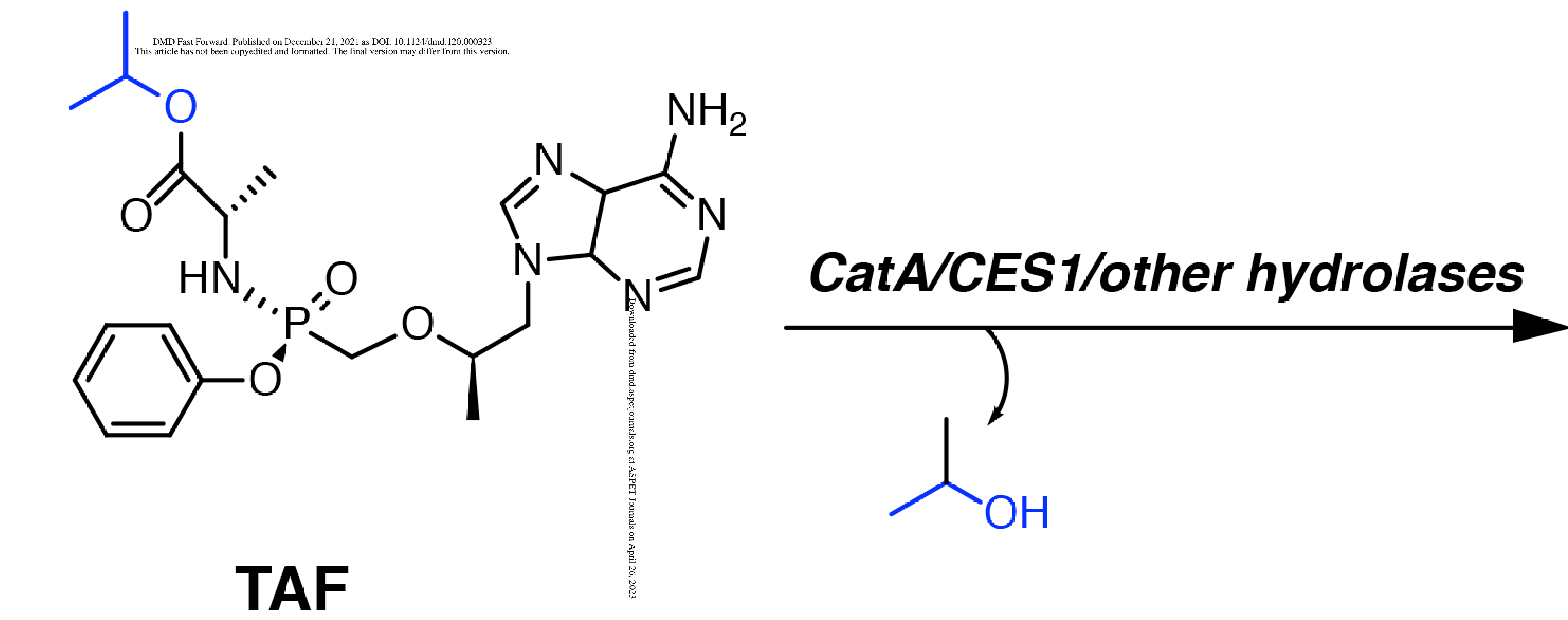

TAF

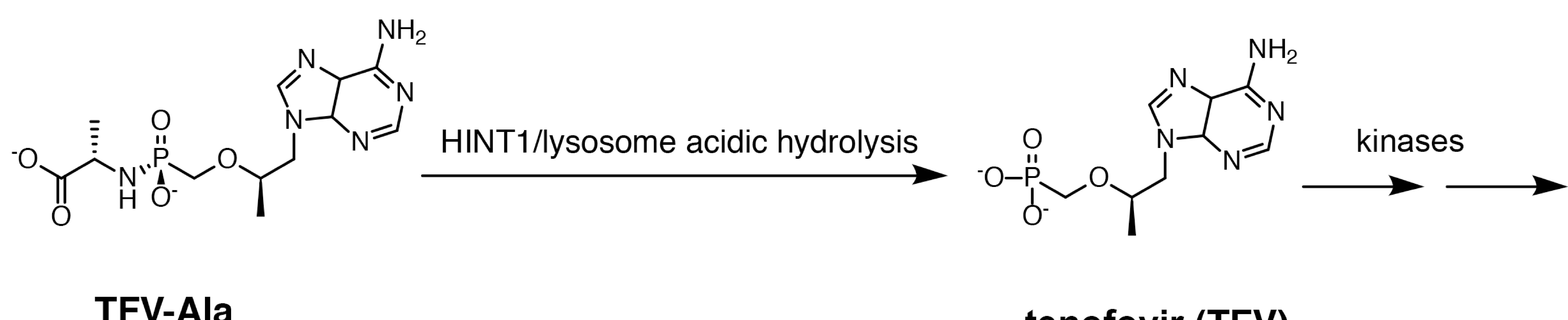
tenofovir (TFV)

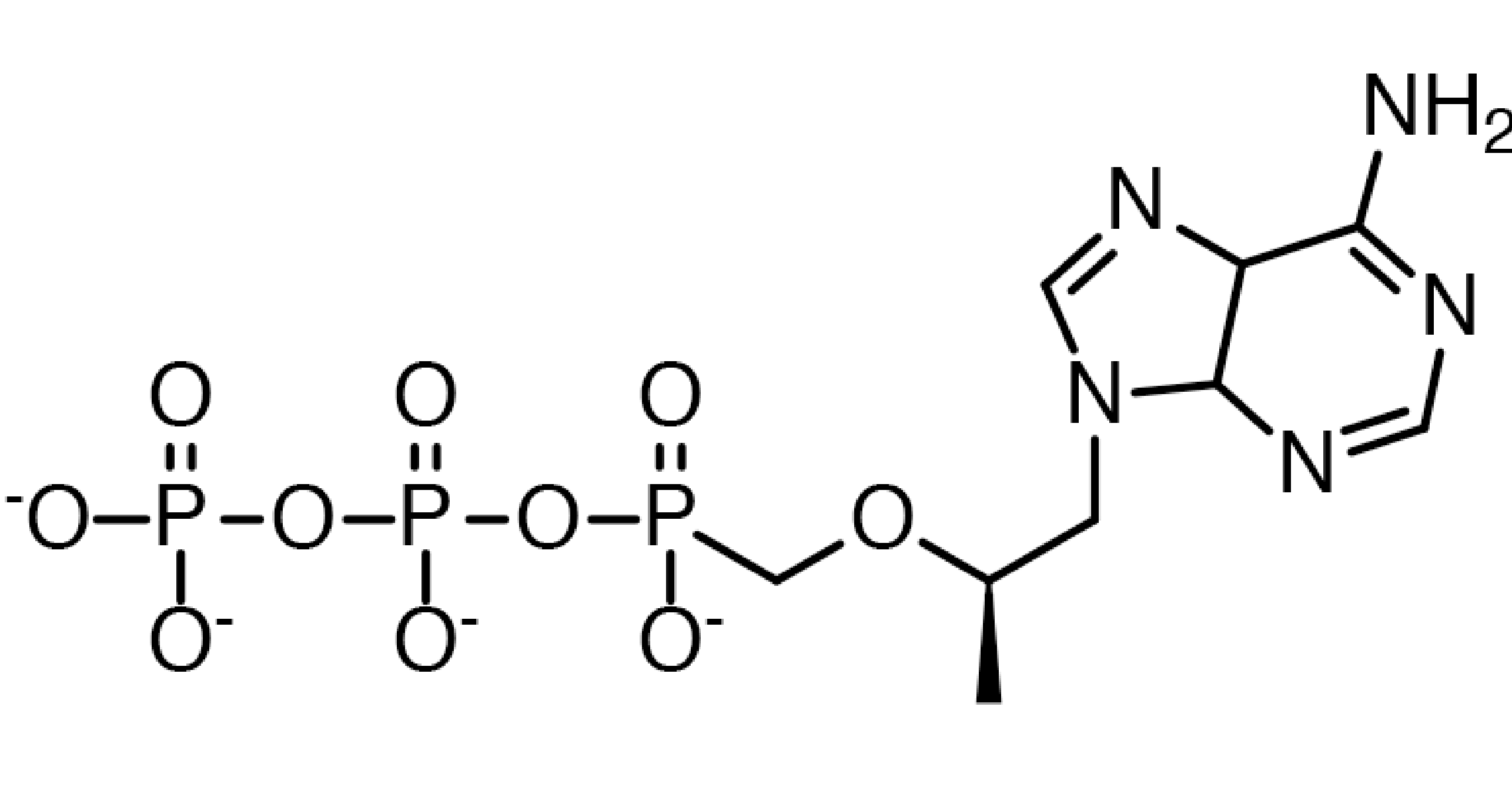

TFV-DP active metabolite 
a

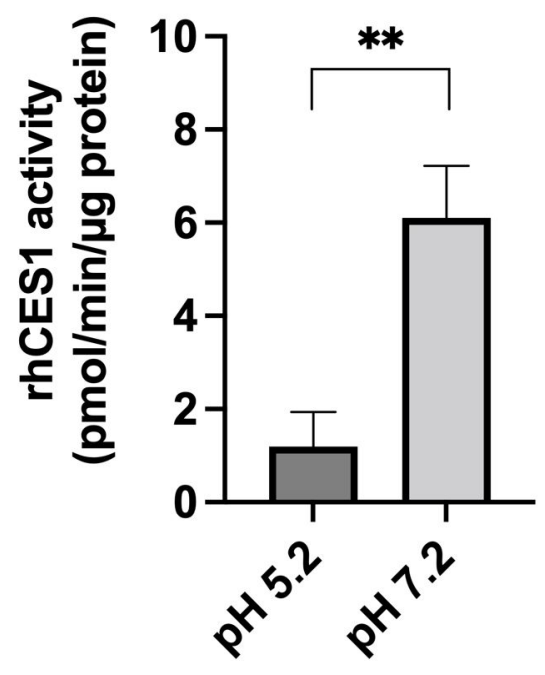

b

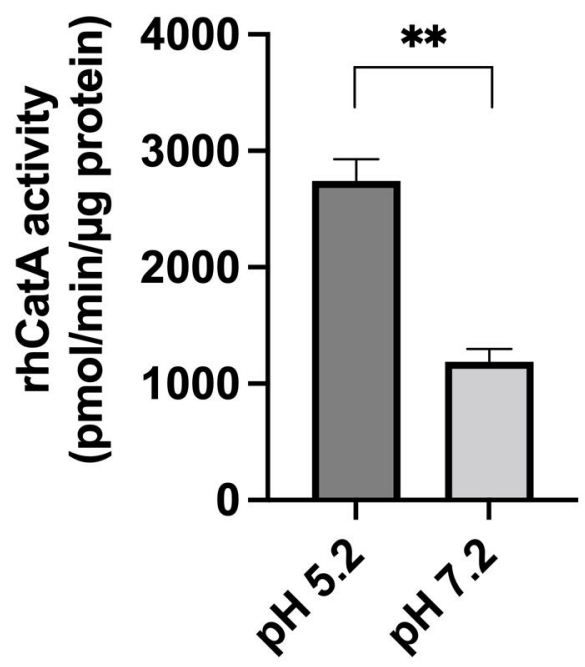

C

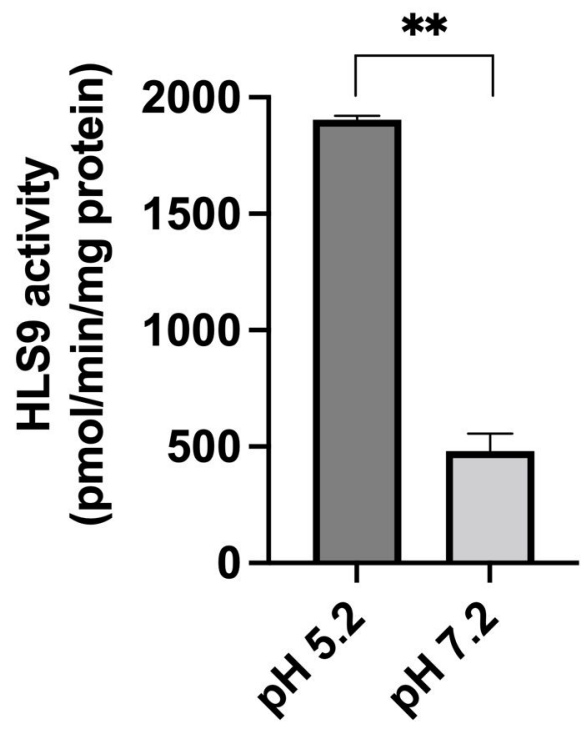


a

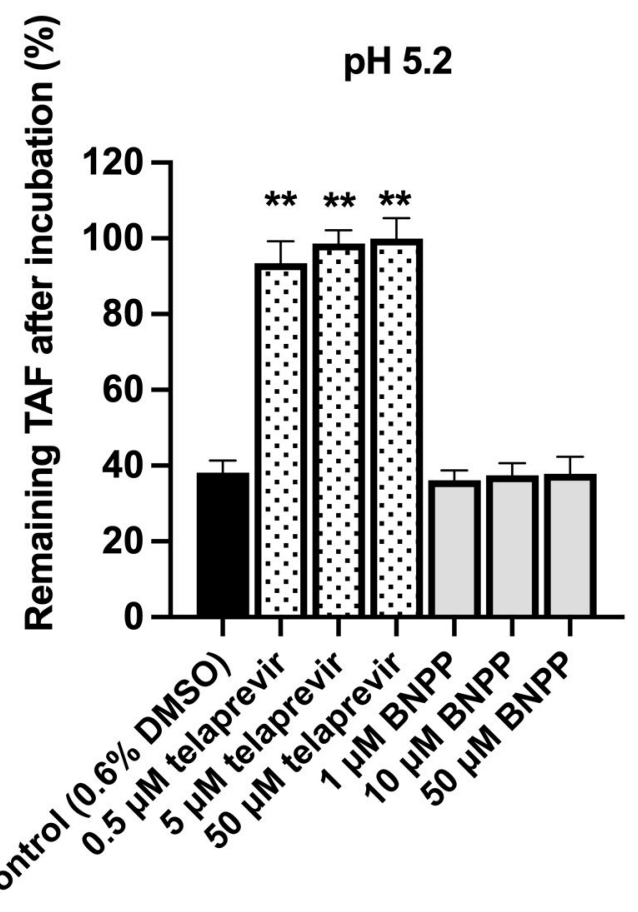

b

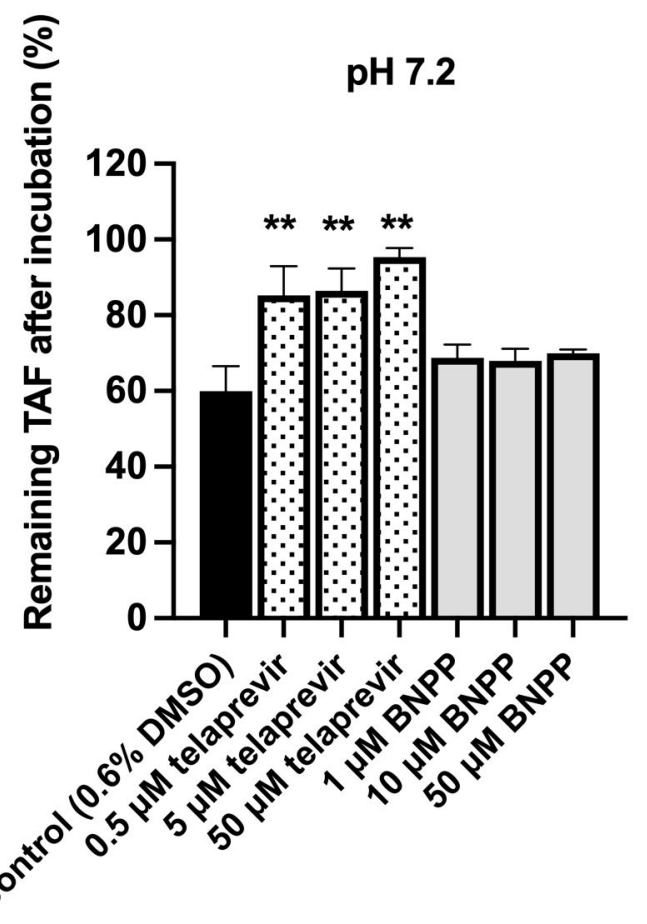


Figure 4

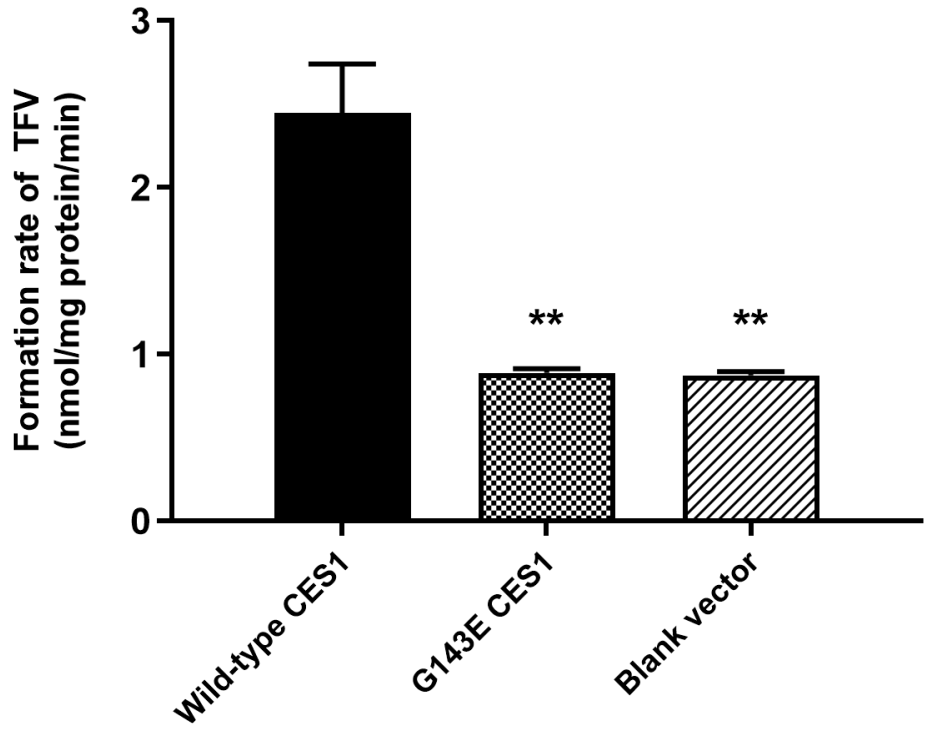

